\section{What effect will the new faces have?}

from Colin Norman, Washington

THE results of last week's elections in the United States are simple to relate. The Democrats strengthened their hold on Congress, and they now occupy more than two-thirds of the seats in the House of Representatives and three-fifths of the seats in the Senate. (All members of the House of Representatives were up for re-election and one-third of the Senators.) The new Congress, which takes office in January, will be younger and probably more liberal than the present one, and there will be more new faces on Capitol Hill than at any time since the Second World War.

What do these changes mean for science? It is important to bear in mind two factors. The first is that because of the so-called seniority system, under which committee chairmanships are given to the longest serving members of the majority party, the newcomers will have little direct power. Few committee chairmen will be leaving this year and therefore the people who wielded the power in this Congress will continue to pull the strings in the next. The second factor is that party labels don't necessarily mean much when it comes to voting on specific issues since there is a wide spread of political opinion among members of both parties.

Nevertheless, there are a few changes in important positions on committees which deal with science and technology, with the Joint Committee on Atomic Energy being the most directly affected. Six out of the eighteen members of that committee either lost in last week's election or will be retiring at the end of this year, and the departures include two of the most influential members - Chet Holifield and Craig Hosmer. Since virtually every member of the joint committee is now a firm supporter of nuclear power, if even as few as one or two of the vacancies are filled by environmentalists or other nuclear sceptics the result would be important in changing the way the committee conducts its affairs.

Another significant departure is that of John Davis, the Chairman of the House Subcommittee on Science, Research and Development, who lost a primary election earlier this year. That subcommittee is the focal point for deliberations on general science policy matters in the House of Representatives and it also oversees the workings of the National Science Foundation. Davis's place will probably be filled by James Symington, a young and widely respected legislator from Missouri who can be expected to step up the pace of the subcommittee's activities. Davis was also a member of the governing board of the Office of Technology Assessment and was in line to be its chairman.

Aside from direct dealings with science and technology, the new Congress is expected to be more sympathetic to environmental concerns because several Congressmen and Senators opposed by environmental groups were defeated. Among them were eight Congressmen listed earlier this year as the House's "Dirty Dozen" by a group called Environmental Action. In addition, twelve of seventeen candidates supported by the League of Conservation Voters were successful in the polls.

Those results have been greeted by environmental groups as proof that, in spite of the present concern about energy shortages, environmental issues are still politically potent. In particular, the results from Colorado indicate that environmental concerns there played a strong part in the election of a Senator, the Governor and at least one member of the House of Representatives. The upshot could be a setback to the government's plans to promote the extraction of oil from shale and the production of natural gas from deep deposits under the Rocky Mountains.

In the Senate election, Gary Hart, who was $\mathrm{Mr}$ McGovern's campaign manager in 1972, defeated Senator Peter Dominick after lambasting Dominick's voting record on environmental matters. As for the governorship, a state legislator, Dick Lamm, who had strongly supported laws to control urban growth in Colorado, defeated the incumbent governor. And in addition, Colorado voters approved a proposition on their ballot papers that before any more underground nuclear blasts can be set off in that state as part of a programme to extract natural gas from tight deposits, a referendum must first be held. The result of that move is likely to be the final blow for the Atomic Energy Commission's Plowshare Project.

Furthermore, environmentalists have hailed the election of other state governors, such as Edmund Brown in California and Edward Herschler in Wyoming, who are considered to be sympathetic to their views.

The election results may also portend some changes in the area of health, since many Congressmen supported by the American Medical Association (AMA) were defeated. One possible result may be to improve the chances that Congress will give its approval in the next two years to a meaningful national health insurance scheme. The AMA, which is vigorously opposed to anything but a minimal health insurance scheme, poured about $\$ 1$ million into the campaign chests of Congressmen who supported its policies.

Perhaps the over-riding concern during the election campaign, however, was inflation and that will also have a direct bearing on the way in which Congress deals with some scientific matters. The Democrats have now been given a strong electoral mandate to curb inflation and they will be likely during the next two years to keep a strong hand on the federal government's purse strings, with the result that few controllable items in the budget will be allowed to grow. Energy research and development can be expected to escape the worst of the squeeze and so, perhaps, can such politically sensitive areas as cancer research. But for the rest of the science budget, a period of austerity should be anticipated.

\section{Soviet failure on the moon}

from Vera Rich

ONE of the happier results of SovietUnited States cooperation in space research must surely be the increasing openness of the Soviet planners about their failures. In the early days, the possibility of failure did not existaborted interplanetary craft were discreetly registered under the cover-all of the Kosmos programme, and probes which failed to send back data were said to have "completed their mission" by the mere fact of effecting a landing or fly-by. The announcement of the Luna-23 failure comes with rather startling frankness.

True, 1974 has not been one of the most spectacular years for the Soviet space programme. Three out of four Mars probes failed to operate on reaching the planet, and the rather coy manoeuvering of the manned Soyuz-15 around the unmanned Salyut-3 in August caused wide speculation that a link-up had been originally intended. In these cases, however, the TASS reports did suggest certain positive achievement. However, Luna-23, launched on October 28 in good time for the Revolution Day celebrations, and hailed as part of the festal "illuminations" in a Pravda article of November 6 , seems to have been officially recorded as a failure. Intended to carry out drilling operations to a depth of $2.5 \mathrm{~m}$, it touched down in a rough area of the Mare Crisium, wrecked its drilling gear, and, after transmitting data for three days (which coincided neatly with the Revolution holidays) ceased functioning. 